Misr J. Ag. Eng., 26(2): 1036- 1053

BIOLOGICAL ENGINEERING

\title{
PHYSICAL AND MECHANICAL PROPERTIES OF PONKAN MANDARIN APPLIED TO GRADING MACHINE
}

\section{Yehia ${ }^{(1)}$, M. H. Kabeel ${ }^{(1)}$ and M. M. Abdel Galeel ${ }^{(3)}$}

\begin{abstract}
The aim of this research is to study some physical and mechanical properties of Ponkan mandarin, as promising fruits, to help the design of handling machines. The physical and mechanical properties are incorporated in the development of the grading machine as a case study. The main results in this study can be summarized in the following points: Physical properties of Ponkan mandarin fruits: diameter $=58.61-85.56$ $\mathrm{mm}$, height $=49.45-78.9 \mathrm{~mm}$, mass $=70-128 \mathrm{~g}$, volume $=60-120$ $\mathrm{cm}^{3}$, projected area $=41.22-81.88 \mathrm{~cm}^{2}$, peel thickness $=2.18-3.73$ $\mathrm{mm}$, peel mass $=24.2-36.1 \mathrm{~g}$, number of segments/fruit $=8-12$, number of seeds/fruit $=4-9$, juice volumelfruit $=23-34 \mathrm{~cm}^{3}$, and juice volumelfruit mass $=0.24-0.45 \mathrm{~L} / \mathrm{kg}$. Mechanical properties of Ponkan mandarin: The average of firmness distribution along Ponkan mandarin surface were: the maximum $=18.3 \mathrm{~N} / \mathrm{cm}^{2}$ at the top of fruit and the minimum $=11 \mathrm{~N} / \mathrm{cm}^{2}$ at the bottom of fruit. The deformation range increased from 2.75 - 3.09 to $8.52-10.02 \mathrm{~mm}$ by increasing loading from 1 to $5 \mathrm{~kg}$. Meanwhile, the deformation range increased from $2.75-8.52$ to 3.09 - 10.02 by increasing loading time from 15 to $60 \mathrm{~s}$.

Some application to grading machine is given also in the paper as a case study.

\section{INTRODUCTION}

itrus are the major horticultural crops in Egypt. The cultivated
area of citrus is 346.24 thousand feddans ( 145.42 thousand
hectare) in 2002 . The areas of orange, tangerine and lemon are
about 210,94 and 38 thousand feddans $(88.2,39.48$ and 15.96 thousand
hectare) respectively. The total annual production of citrus in Egypt is
about 2.8 million ton in 2002 .
\end{abstract} (1) and (2) Senior Res. and Res., Ag. Eng. Res. Inst. respectively. 
The productions of orange, mandarin (Citrus deliciosa. Blanco) and lemon are about 181, 602 and 334 thousand tons respectively.

Egypt citrus exports quantity increased from 195 to 416 thousand tons which gave 53.6 to 99.8 million U. S. $\$$ (1 U. S. $\$=2.80$ according to Egyptian Central Bank) from 2000 to 2003 (H. R. I., 2004).

Tangerines are not exported because of variability and size and shape and lack of proper packaging. Consumers prefer fruits with equal weight and uniform shape. Mass grading of fruit can reduce packaging and transportation costs, and also may provide an optimum packaging configuration (Peleg et al.,1985).

In Egypt, there are various mandarin varieties varied in their productivity, fruit maturity and quality. Alternate bearing is one of the most disadvantages in Baladi mandarin (اليوسفى البلدى), beside great number of seeds per fruit and small fruit size.

Ponkan tangerine (Citrus reticulate. Blanco) is one of promising mandarin varieties. It has many advantages in vigorous growth fruiting, fruit mass, volume and quality may be helpful in this respect.

Agamia et al. (1982) reported that the average mass of fruit ranges from about 95 to $140 \mathrm{~g}$, the fruit volume from 100 to $154 \mathrm{~cm}^{3}$ and the diameter from 4 to $6.5 \mathrm{~cm}$ for Nareng, Clementine, Satsuma, Cleopatra, Mallawi and Baladi Mandarins.

Sharawy (1992) found that the number of segements per fruit was about 10 - 11 for Baladi orange, 12 - 13 for Ruby Red grapefruit and 10 - 11 for Baladi mandarin.

Kinawy (1995) found that the average peel thickness, number of segments per fruit, number of seeds per fruit, mass of 100 seeds, and juice percentage were $3.2 \mathrm{~mm}, 11,17.9,12.5 \mathrm{~g}$ and41.5\% respectively for Baladi mandarin; and were $3.9 \mathrm{~mm}, 10.3,11,12.8 \mathrm{~g}$ and $34.2 \%$ respectively for Ponkan tangerine.

Mousa (1998) found that the mean values of diameter ranged from about 69 to $84 \mathrm{~mm}$; height ranged from about 57 to $87 \mathrm{~mm}$; mass ranged from about 160 to $208 \mathrm{~g}$; volume ranged from 188 to $241 \mathrm{~mm}$ for Navel, Baladi, Acidless and Valencia orange varieties. The height values limited the distance between grading lines and shape and size of the distributed buckets on the conveyor belt. According to that, the bucket design was: 
length of $650 \mathrm{~mm}$ and diameter of $100 \mathrm{~mm}$ more than the biggest height of orange fruits.

Yehia (2001) found that the ranges of peel thickness, number of segments and bulk density were $3.21-3.5 \mathrm{~mm}, 10-12$ and $440-450 \mathrm{~kg} / \mathrm{m}^{3}$ respectively for Baladi orange. The average friction angles were 12.68, $12.9,12.73,12.84$ for non-galvanized, galvanized, aluminum and stainless steal respectively for Baladi orange. The physical and mechanical properties were incorporated in the design of the feeding mechanism (fruit dimensions, bulk density and friction and rolling angles), orange tube (fruit dimensions), holding mechanism (fruit dimensions and peel thickness) and press mechanism (fruit dimensions and peel thickness) of the designed automatic-juicer.

Awady et al. (2004) concluded that the physical properties of Minneola fruits which had oblong shape were: diameter $=62-89 \mathrm{~mm}$, height $=68-$ $104 \mathrm{~mm}$, mass $=201-345 \mathrm{~g}$, volume $=120-342 \mathrm{~cm}^{3}$, projected area $=$ $54-108 \mathrm{~cm}^{2}$, peel thickness $=3-5 \mathrm{~mm}$, peel mass $=52-73 \mathrm{~g}$, number of segments/fruit $=9-12$, number of seeds/fruit $=2-8$, juice volume/fruit $=$ $96-168 \mathrm{~cm}^{3}$, and juice volume/fruit mass $=0.41-0.59 \mathrm{~L} / \mathrm{kg}$. Whereas, the mechanical properties of Minneola: The deformation range increased from $2.75-3.09$ to $8.52-10.02 \mathrm{~mm}$ by loading from 1 to $5 \mathrm{~kg}$. Meanwhile, the deformation range increased from 2.75 - 8.52 to 3.09 10.02 by increasing loading time from 15 to $60 \mathrm{~s}$.

Khanali et al. (2007) concluded that a very good relationship between mass $(\mathrm{M})$ and measured volume $(\mathrm{V})$ of tangerines for all varieties $(\mathrm{M}=$ $0.99 \mathrm{~V}-5.52$ ) with $\mathrm{R}^{2}$ in the order of 0.96 .

The objective of present research is to study some physical and mechanical properties of Ponkan tangerine, as a data base, as promising fruits, to help the design of handling machines. The physical and mechanical properties are incorporated in the development of the grading machine as a case study.

\section{MATERIALS AND METHODS}

\section{a. Fruits.}

Ponkan mandarin crop was considered in this study. All measurements were done using a random sample of 100 fruits. The samples were taken Misr J. Ag. Eng., April 2009 
randomly from Ponkan mandarin trees (special farm in El Qanater El Khairia at acceptable harvesting date) and from "El Oboor" (سوق العبور) Market; and the measurements were taken in the same day.

\section{b. Instrumentation:}

b1. Digital caliper with vernier: with accuracy of $0.01 \mathrm{~mm}$, to measure different dimensions of Ponkan-mandarin fruits.

b2. Digital balance: with accuracy of $0.2 \mathrm{~g}$, to measure mass of Ponkan-mandarin fruits and constituents (peel, seeds and juice).

b3. Graduated cylinder: of $1000 \mathrm{~mL}$ with accuracy of $25 \mathrm{~mL}$ to determine the real density and volume of fruit by immersion in water.

b4. Friction and rolling-angle measuring device: An inclined plane was used to measure friction and rolling angles.

b5. Friction angle measurement: the fruits are placed as a group bounded together on a horizontal surface then the angle of inclination is gradually increased until the fruits begin sliding without rolling. For each fruits group of an average sample of (10), the friction angles were determined.

b6. Rolling angle measurement: the fruits are placed on a horizontal surface one by one then the angle of inclination is gradually increased until the fruits begin roll. For each fruit of an average sample (50), two angles of rolling are determined: for the maximum stable (with their base down) and minimum stable positions.

b7. Bulk density and angle of repose: Sample of Minneola of not less than $20 \mathrm{~kg}$, was put into a box with transparent walls. The box is kept on its side position "a" (fig. 1). Box dimensions are at least 1000 x $300 \mathrm{x}$ $200 \mathrm{~mm}$. The free surface of Minneola is leveled and height "L" is measured. By multiplying "L" by the area of the side wall, the sample volume is found and the bulk density is calculated in the usual manner. After this, the box is gradually tilted into a horizontal position. The free surface of mass then makes an acute angle " $\alpha$ " with respect to the 
horizontal. "H" and "l" are measured with a ruler scale and angle of repose is calculated by the expression " $\tan \alpha=H / l "$. The experiment was repeated 5 times and the mean value of " $\alpha$ " is calculated from these values.

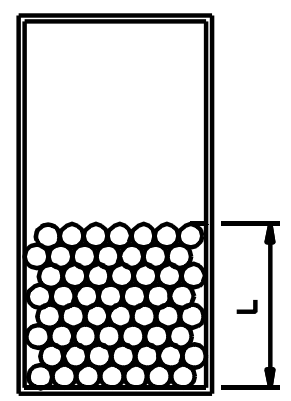

a

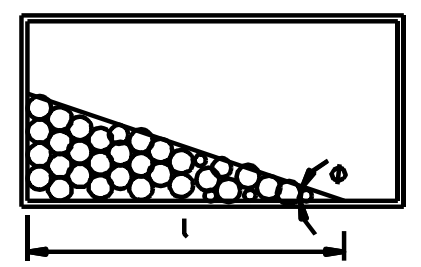

b

Fig. 1: Bulk density and angle of repose measuring box.

b.8 Penetrometer: Penetrometer, made in Italy, with accuracy of $0.1 \mathrm{~N}$ was used to measure penetration force of Minneola fruits. The firmness of fruit was obtained by dividing the penetration force by the area $\left(0.28 \mathrm{~cm}^{2}\right)$ of cylindrical probe, which had $0.6 \mathrm{~cm}$ diameter.

b.9 Deformation tester: The non-destructive deformation tester was developed and constructed according Atta-Aly and Awady, 1994. Its shape and dimensions are shown in fig. 2. Stainless steal was used for constructing basic elements. Tester was designed with an accuracy of $0.01 \mathrm{~mm}$ strain and an open scale to accept loads ranging from $1 \mathrm{~g}$ up to $10 \mathrm{~kg}$. Both arm and height adjustments can be manually set to fit any fruit size when different fruit species or cultivars are used.

\section{c. Equations and calculations:}

The following equations were used to calculate sphericity, projected area and real density according to Mohsenin, 1986 (fig. 3).

Sphericity ratio $=$ fruit height $(\mathrm{H}) /$ fruit diameter $(\mathrm{D})$

Projected area $=4 / \pi(D * H)$

Real density $=$ Mass $/$ Volume 


\section{d. The developed grading machine:}

Fig. 4 shows a schematic diagram design-idea of the grading machine. Parameters shown on the figure are essentially those to be determined for Ponkan mandarin through this work, for modifying the grading machine to operate efficientlv on this fruit.

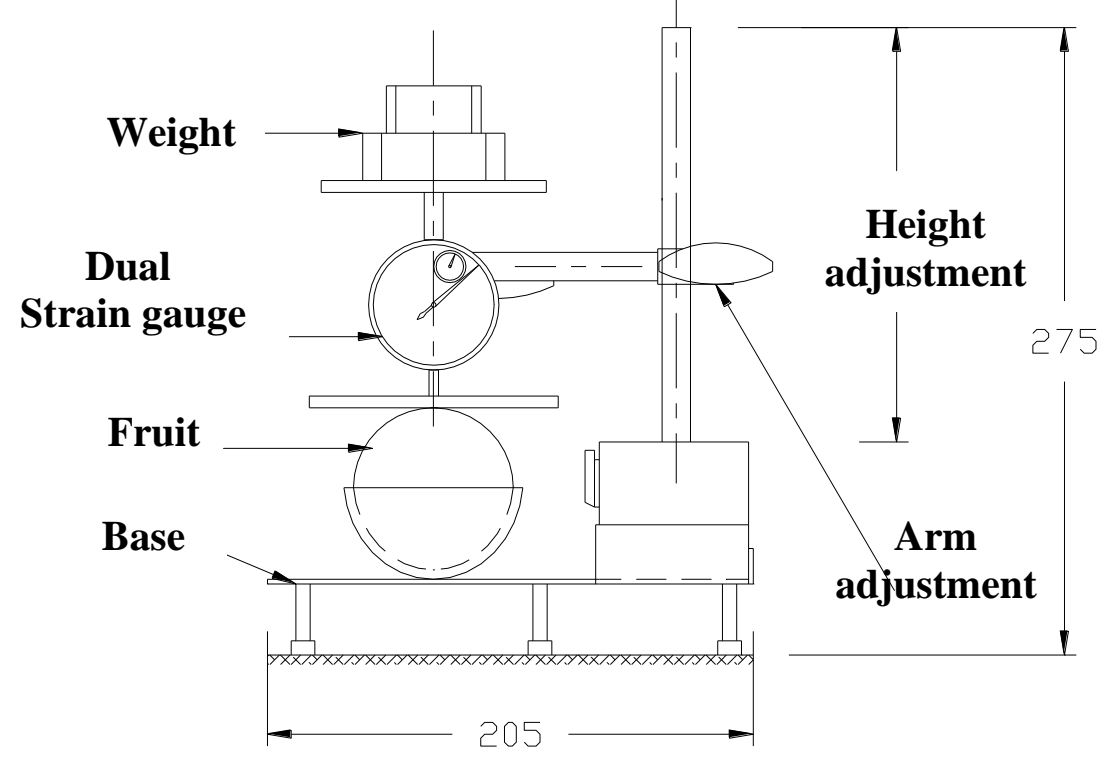

Fig. 2: Diagram of deformation tester.

(Atta-Aly and Awady, 1994).

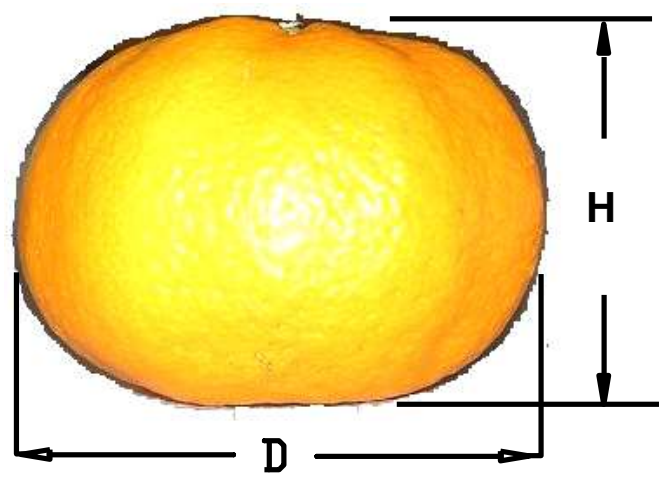


Fig. 3: View of Ponkan mandarin fruit



Fig. 4: Diagram demonstrating idea of a grading machine, with the numbers in brackets indicating parameters necessary for design of different parts.

\section{Associated parameters:}

(1) Fruit dimensions, (2) Bulk density, (3) Friction and rolling angles, (4) Fruit mass, and (5) Fruit firmness.

Other physical and mechanical properties in this paper (such as juice volume and mass, peel thickness, and number and mass of seeds) was conducted as a data base to help the design of some handling machines such as juice extracting machines.

\section{RESULTS AND DISCUSSION}

\section{a. Physical properties of Ponkan mandarin fruits.}


Table 1 shows dimensions, sphericity, mass, volume, real density, projected area, peel thickness and mass, juice volume, juice volume/fruit mass ratio and juice density of Ponkan mandarin fruits. These data were measured on 100 fruit sample, according to the standards set in (Mohsenin, 1986).

Table 1: Physical properties of Ponkan mandarin fruits.

\begin{tabular}{|l|c|c|c|c|c|}
\hline Physical properties & Max. & Min. & Average & S. D. $^{(1)}$ & C. V. $^{(2)}$ \\
\hline Height, mm & 85.56 & 58.61 & 72.58 & 6.38 & 8.99 \\
\hline Diameter, mm & 78.9 & 49.5 & 60.19 & 4.86 & 9.30 \\
\hline Sphericity & 1.29 & 0.68 & 0.84 & 0.11 & 12.98 \\
\hline Mass, g & 128.4 & 70.8 & 91.1 & 12.7 & 13.95 \\
\hline Volume, $\mathrm{cm}^{3}$ & 120 & 60 & 86.8 & 14.45 & 7.45 \\
\hline Bulk density, g/cm ${ }^{3}$ & \multicolumn{5}{|l|}{718.63} \\
\hline Real density, g/cm ${ }^{3}$ & 1.08 & 0.81 & 0.95 & 0.07 & 7.65 \\
\hline Projected area, cm ${ }^{2}$ & 81.88 & 41.22 & 55.75 & 8.03 & 14.4 \\
\hline Peel thickness, mm & 3.73 & 2.18 & 2.8 & 0.39 & 13.86 \\
\hline Peel mass, g & 36.1 & 24.2 & 31.82 & 2.89 & 3.08 \\
\hline No. of segments/fruit & 12 & 8 & 10 & 0.91 & 8.68 \\
\hline No. of seeds & 9 & 4 & 6 & 1.37 & 22.98 \\
\hline Seed mass, g & 1.6 & 0.2 & 0.85 & 0.23 & 26.77 \\
\hline Juice density, g/cm ${ }^{3}$ & 1.08 & 0.81 & 0.9 & 0.05 & 5.24 \\
\hline $\begin{array}{l}\text { Juice volume cm3 } \\
\text { Juice volume/fruit } \\
\text { mass, L/kg }\end{array}$ & 0.45 & 0.24 & 0.32 & 0.05 & 14.96 \\
\hline Juice density, g/cm3 & 1.08 & 0.81 & 0.9 & 0.05 & 5.24 \\
\hline
\end{tabular}

(1) S. D. is standard deviation.

(2) C. V. is coefficient of variation.

\section{a1. Dimensions of fruit:}

Fig. 5 indicates that the fruit diameter and height ranges of sample were $55.51-85.56 \mathrm{~mm}$ (average $72.90 \mathrm{~mm}$ ) and $49.45-78.90 \mathrm{~mm}$ (average $59.87 \mathrm{~mm}$ ) respectively. The most frequent percent $(85 \%)$ of Ponkan mandarin fruits in the sample have $65-80 \mathrm{~mm}$ diameter and $(89 \%)$ of Ponkan mandarin fruits in the sample have 55 - $65 \mathrm{~mm}$ height.

\section{a2. Shape and size of fruit:}

If sphericity is less than 0.9 , the fruit belongs to oblate group; if sphericity is greater than 1.1, it belongs to oblong group. The remaining fruits with Misr J. Ag. Eng., April 2009 
intermediate index values are considered to be round (Buyanov and Voronyuk, 1985).

Fig. 6 indicates that the fruit spericity ranged in sample between 0.7 and 1.3. The most frequent percent $(59 \%)$ of Ponkan mandarin fruits in the sample was round (sphericity $0.9-1.1),(37 \%)$ of Ponkan mandarin fruits in the sample were oblate (sphericity $0.7-0.8$ ) and $(4 \%)$ of Ponkan mandarin fruits in the sample were oblong (sphericity 1.2 - 1.3).

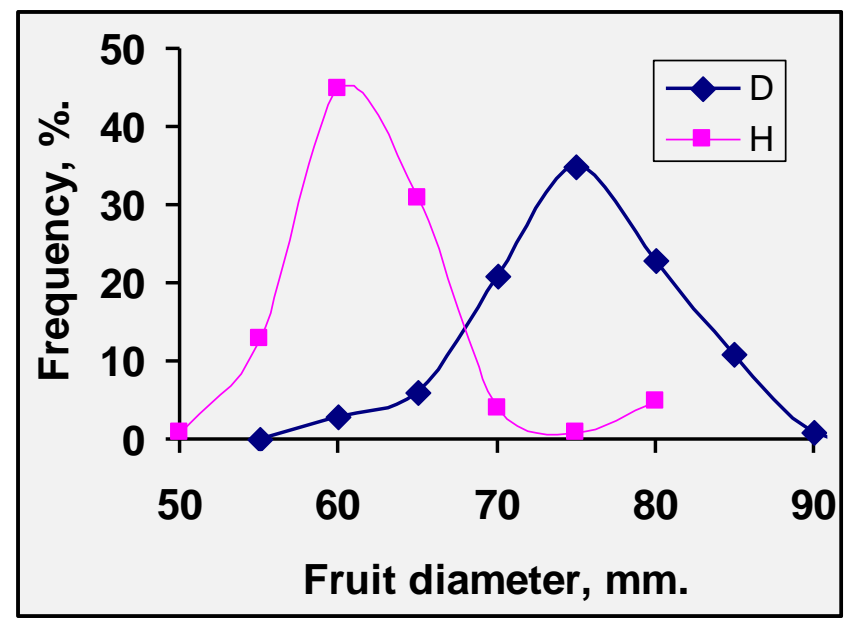

Fig. 5: Frequency curves distribution of fruit dimensions (diameter "D" and height "H") of Ponkan mandarin fruits.

\section{a3. Mass and volume of fruit:}

Fig. 7 indicates that the fruit mass and volume ranges of sample were 70 $128 \mathrm{~g}$ (average $91.10 \mathrm{~g}$ ) and $60-120 \mathrm{~cm}^{3}$ (average $86.8 \mathrm{~cm}^{3}$ ) respectively. The most frequent percent $(82 \%)$ of Ponkan mandarin fruits in the sample had $80100 \mathrm{~g}$ mass and $(74 \%)$ had $80-100 \mathrm{~cm}^{3}$ volume.

Fig. 8 shows the best fitted curves and the relation between fruit mass (M) and volume $(\mathrm{V})$ of Ponkan mandarin as follows:

$$
\mathrm{M}=0.94 \mathrm{~V}+0.91, \mathrm{R}^{2}=0.81
$$

\section{a4. Real density of fruit:}

Fig. 9 indicates that the fruit real density of sample ranged between 0.81 and $1.08 \mathrm{~g} / \mathrm{cm}^{3}$ (average $0.95 \mathrm{~g} / \mathrm{cm}^{3}$ ). The most frequent percent $(74 \%)$ of Ponkan mandarin fruits in the sample had $0.9-1.0 \mathrm{~g} / \mathrm{cm}^{3}$ real density. 


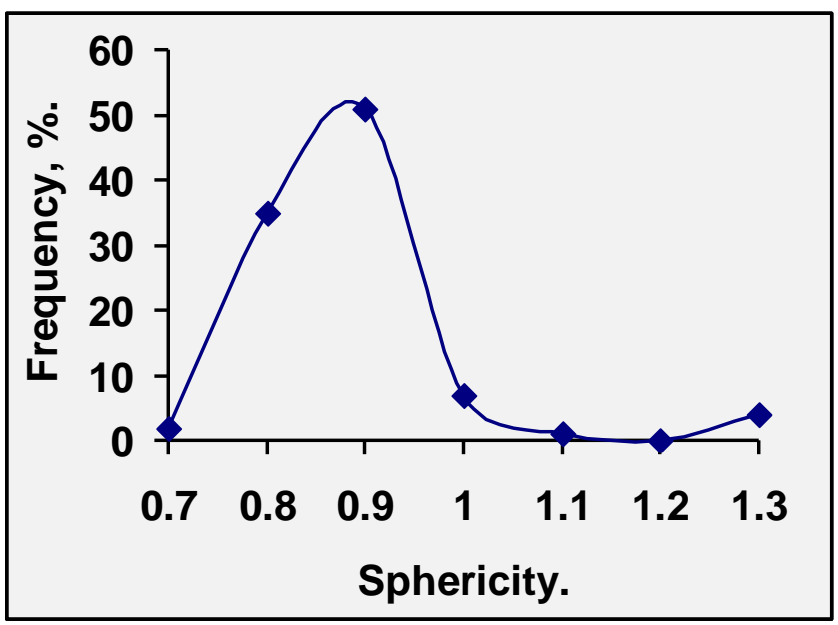

Fig. 6: Frequency distribution of fruit sphericity of Ponkan mandarin fruits.
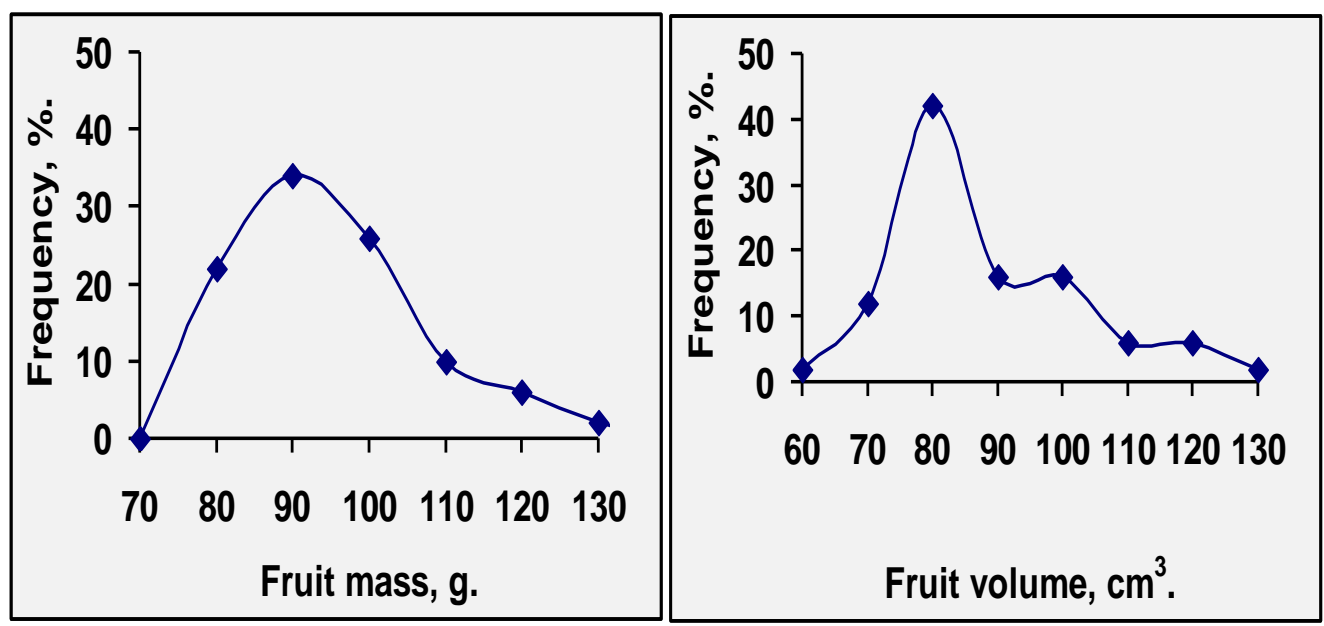

Fig. 7: Frequency curves distribution of fruit mass and volume of Ponkan mandarin fruits. 


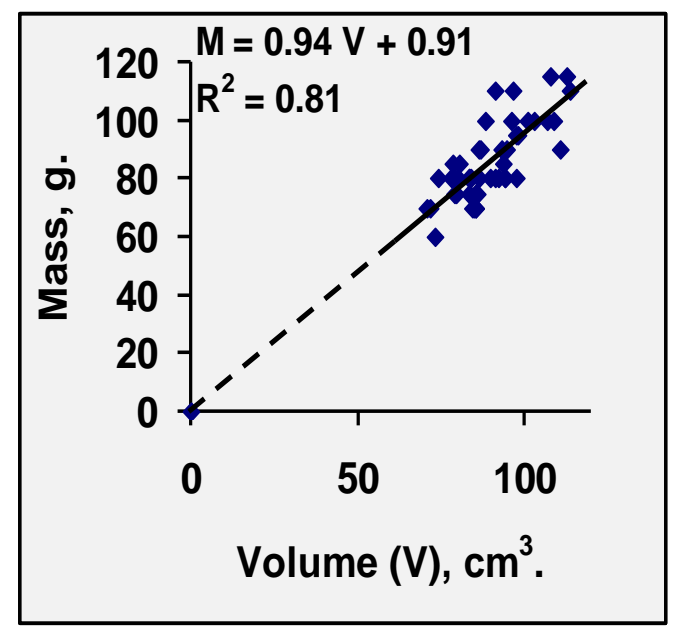

Fig. 8: The best fitted curves shows the relations between fruit volume and mass of Ponkan mandarin fruits.

\section{a5. Projected area of fruit:}

Fig. 9 indicates that the fruit projected area of sample ranges between 41.22 and $81.88 \mathrm{~cm}^{2}$ (average $55.75 \mathrm{~cm}^{2}$ ). The most frequent percent (95 $\%$ ) of Ponkan mandarin fruits in the sample have $50-70 \mathrm{~cm}^{2}$ projected area.
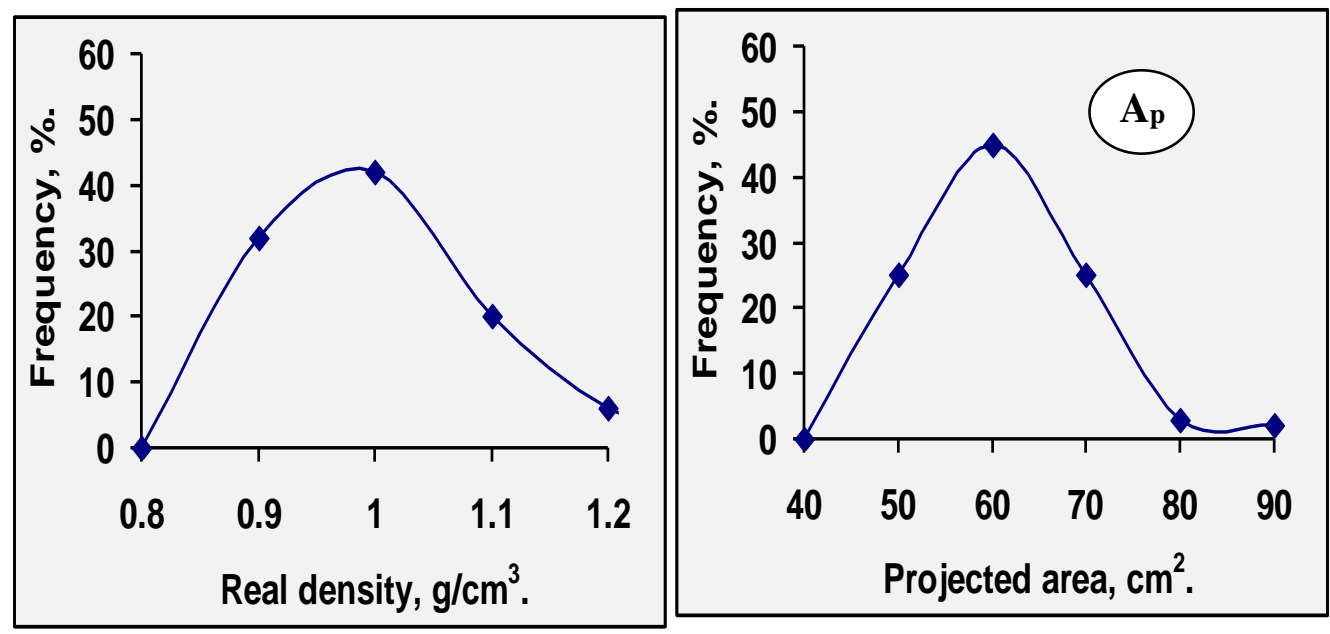

Fig. 9: Frequency curves distribution of fruit mass and real density and projected area $\left(A_{p}\right)$ of Ponkan mandarin fruits. 


\section{a6. Peel thickness and mass:}

Fig. 10 indicates that the peel thickness and mass ranges of sample were $2.18-3.73 \mathrm{~mm}$ (average $2.8 \mathrm{~mm}$ ) and $24.2-36.1 \mathrm{~g}$ (average $31.82 \mathrm{~g}$ ) respectively. The most frequent percent $(88 \%)$ of Ponkan mandarin fruits in the sample have $2.5-3.25 \mathrm{~mm}$ thickness and (78 \%) have 32 - $36 \mathrm{~g}$ mass.
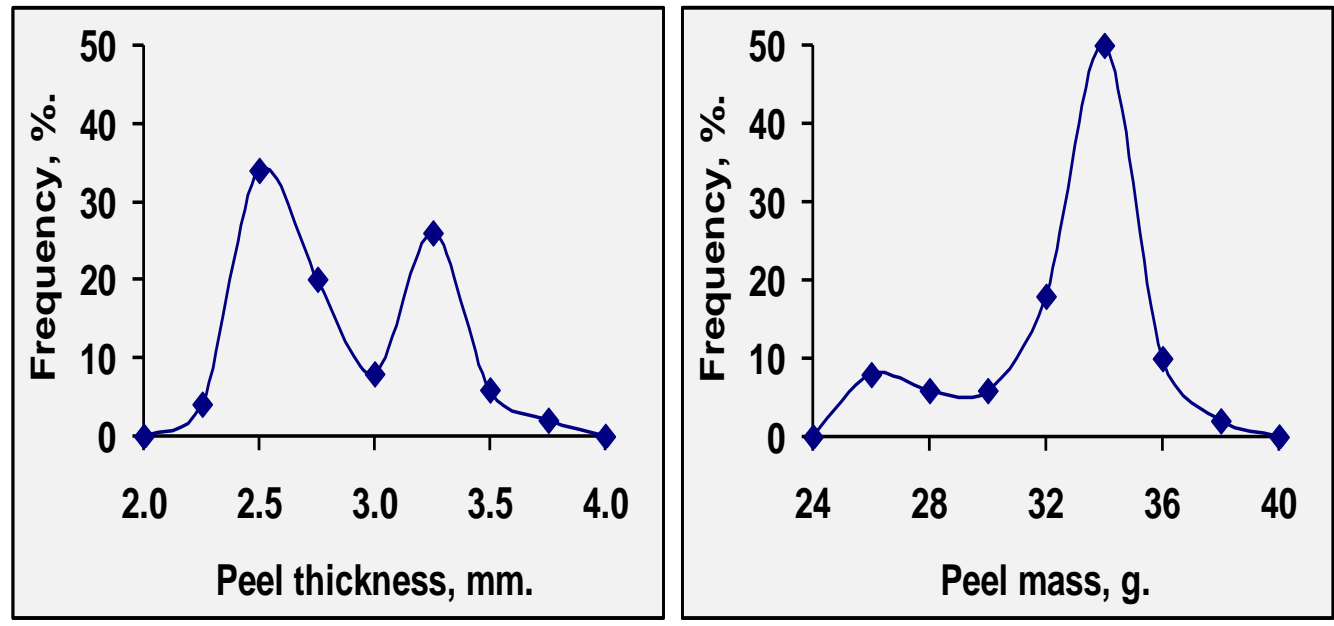

Fig. 10: Frequency curves distribution of peel thickness and mass of Ponkan mandarin fruits.

\section{a7. Number of segments and seeds per fruit:}

Fig. 11 indicates that the number of segments and seeds ranges of sample were 8 - 12 (average 10) and 4 - 9 (average 6) respectively. The most frequent percent $(94 \%)$ of Ponkan mandarin fruits in the sample had 10 12 segments/fruit and (90\%) had 4 - 7 seeds/fruit.

\section{a8. Juice volume and juice volume/fruit mass ratio:}

Fig. 12 indicates that the juice volume/fruit and juice volume/fruit mass ratio ranges of sample were $23-34 \mathrm{~cm}^{3} /$ fruit (the average is 28.76 $\mathrm{cm}^{3} /$ fruit) and $0.24-0.45 \mathrm{~L} / \mathrm{kg}$ (average $0.32 \mathrm{~L} / \mathrm{kg}$ ) respectively. The most frequent percent $(96 \%)$ of Ponkan mandarin fruits in the sample had $26-32 \mathrm{~cm}^{3}$ juice volume/fruit and $(84 \%)$ of Ponkan mandarin fruits in the sample had $0.3-0.4 \mathrm{~L} / \mathrm{kg}$ juice volume/fruit mass. 



Fig. 11: Frequency curves distribution of number of segments and seeds/fruits of Ponkan mandarin fruits.
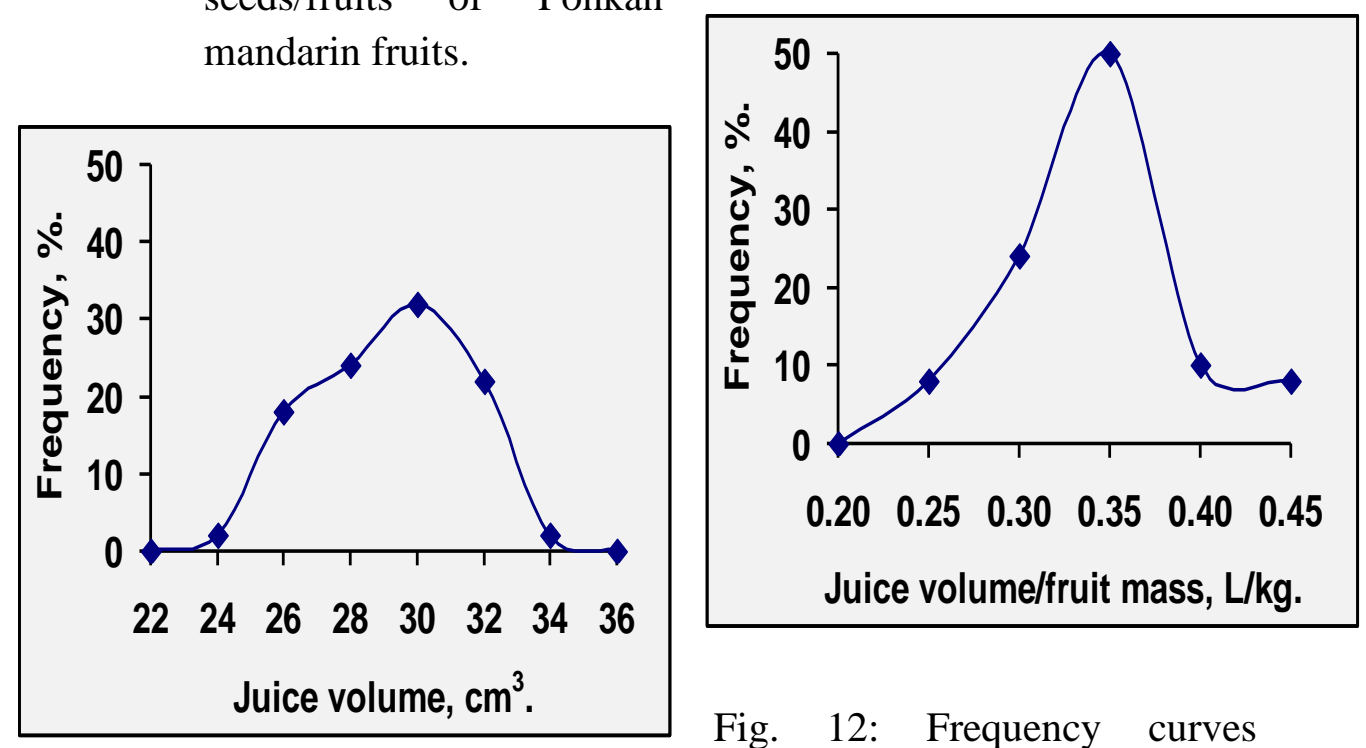

Fig. 12: Frequency curves distribution of juice volume/fruit and juice volume/fruit mass ratio of Ponkan mandarin fruits.

\section{b. Mechanical properties of Ponkan mandarin fruits.}

\section{b1. Friction, rolling and repose angles of Ponkan mandarin fruits:}

Table 2-2 shows friction and rolling angles of Ponkan mandarin fruits.

The maximum friction angle (38 - 43 degree) and rolling angle ranges (23 
- 32 degree) were obtained with wood surface. Whereas, the minimum ranges of friction and rolling angles (15 - 17 and 10 - 24 respectively) were obtained with aluminium surface.

Table 2: Friction and rolling angles for Ponkan mandarin fruits with different surface types.

\begin{tabular}{|c|c|c|c|c|c|c|c|c|c|}
\hline \multirow{2}{*}{$\begin{array}{c}\text { Surface } \\
\text { type }\end{array}$} & \multicolumn{3}{|c|}{$\begin{array}{c}\text { Friction angle, } \\
\text { degree }\end{array}$} & \multicolumn{6}{|c|}{ Rolling angle, degree } \\
\cline { 2 - 10 } & Max. & Min. & Av. & Max. & Min. & Av. & Max. & Min. & Av. \\
\hline Wood & 43 & 38 & 40 & 32 & 23 & 28 & 22 & 17 & 20.5 \\
\hline Metal & 17 & 15 & 15.2 & 24 & 23 & 22.4 & 14 & 11 & 12.5 \\
\hline Galv. I. & 17 & 15 & 14.6 & 24 & 23 & 22.6 & 14 & 11 & 12.7 \\
\hline Alum. & 17 & 14 & 14.4 & 24 & 21 & 22.2 & 14 & 10 & 12.3 \\
\hline SS & 17 & 15 & 14.5 & 24 & 23 & 21.3 & 14 & 11 & 12.4 \\
\hline
\end{tabular}

Wood: wood sheet No. 2; Galv. I.: Galvanized iron; Alum.: Aluminium; and SS.: Stainless steal.

The average repose-angle was about 38.8 degree.

\section{b2. Deformation of fruits:}

Fig. 13 shows the average deformation of Ponkan mandarin fruit at different loading weights and times. The deformation range increased from $0.86-1.04$ to $8.26-9.06 \mathrm{~mm}$ by increasing loading from 10 to 50 $\mathrm{N}$. Meanwhile, the deformation range increased from $0.86-8.26$ to 1.04 $-9.06 \mathrm{~mm}$ by increasing loading time from 15 to $60 \mathrm{~s}$. The final deformation after removing the load (after $60 \mathrm{~s}$ ) increased from 0.44 to $3.07 \mathrm{~mm}$ by increasing loading from 10 to $50 \mathrm{~N}$.

\section{b3. Firmness of Ponkan mandarin fruits:}

The average of firmness distribution along Ponkan mandarin surface were: the maximum $=18.3 \mathrm{~N} / \mathrm{cm}^{2}$ at the top of fruit, the minimum $=11$ $\mathrm{N} / \mathrm{cm}^{2}$ at the bottom of fruit, at $15 \mathrm{~mm}$ from top of fruit $=12 \mathrm{~N} / \mathrm{cm}^{2}$, at 30 $\mathrm{mm}$ from top of fruit $=13.6 \mathrm{~N} / \mathrm{cm}^{2}$, and at $45 \mathrm{~mm}$ from top of fruit $=11.5$ $\mathrm{N} / \mathrm{cm}^{2}$. 




Fig. 13: Relation between loading weight and deformation at different loading time for Ponkan mandarin fruit.

\section{c. Application of the theory to the design of the Ponkan mandarin grading machine:}

Parameters required for development of the design of grading machine have been explained in the part $2 \mathrm{~d}$ in the section on "Materials and Methods". Fig. 4 shows the parameters. Some results of this investigation point out to the following:

The physical and mechanical properties are incorporated in the design of the fruit hopper, revolving drums with holes (length and diameters of drums, diameter of holes, and number of holes) and exit chute of the designed grading-machine as follows:

\section{c1. Fruit hopper (Fig. 4):}

Hopper dimensions: to suit feeding rate and bulk density of fruits $=100 \mathrm{x}$ $60 \times 35 \mathrm{~cm}$ for length, width and height respectively.

Fruit hopper side-slope $=$ more than maximum friction angle of Ponkan mandarin fruits with stainless steal surface $\left(>17^{\circ}\right)=30^{\circ}$.

\section{c2. Grading drums:}

Revolving drums with holes are used to grade the fruits to 5 sizes.

Drum hole diameters $=40,50,60,70$ and $80 \mathrm{~mm}$.

No. of drums to suit No. of Ponkan mandarin categories $=5$.

Rotating drums with holes diameter and length to suit machine productivity $=$ about $40-50 \mathrm{~cm}$ diameter and $100 \mathrm{~cm}$ length. 
Drums tilt-angle $=$ more than maximum rolling angle between Ponkan mandarin fruits and stainless steal surface $=$ more than $24^{\circ}$.

\section{c3. Fruit chute:}

Fruit chute tilt angle $=$ more than maximum friction angle between Ponkan mandarin fruits and stainless steal surface $=$ more than $17^{\circ}$.

\section{CONCLUSION}

The main results in this study can be summarized as follows:

Physical properties of Ponkan mandarin fruits: diameter $=58.61-85.56$ $\mathrm{mm}$, height $=49.45-78.9 \mathrm{~mm}$, mass $=70-128 \mathrm{~g}$, volume $=60-120$ $\mathrm{cm}^{3}$, projected area $=41.22-81.88 \mathrm{~cm}^{2}$, peel thickness $=2.18-3.73$ $\mathrm{mm}$, peel mass $=24.2-36.1 \mathrm{~g}$, number of segments/fruit $=8-12$, number of seeds/fruit $=4-9$, juice volume/fruit $=23-34 \mathrm{~cm}^{3}$, and juice volume/fruit mass $=0.24-0.45 \mathrm{~L} / \mathrm{kg}$.

Mechanical properties of Ponkan mandarin: The average of firmness distribution along Ponkan mandarin surface were: the maximum $=18.3$ $\mathrm{N} / \mathrm{cm}^{2}$ at the top of fruit and the minimum $=11 \mathrm{~N} / \mathrm{cm}^{2}$ at the bottom of fruit.

The deformation range increased from $0.86-1.04$ to $8.26-9.06 \mathrm{~mm}$ by increasing loading from 10 to $50 \mathrm{~N}$. Meanwhile, the deformation range increased from $0.86-8.26$ to $1.04-9.06 \mathrm{~mm}$ by increasing loading time from 15 to $60 \mathrm{~s}$.

The physical and mechanical properties are incorporated in the design of the fruit hopper, revolving drums with holes (length and diameters of drums, diameter of holes, and number of holes) and exit chute of the designed grading-machine as follows:

Fruit Hopper dimensions: to suit feeding rate and bulk density of fruits $=170 \times 60 \times 35 \mathrm{~cm}$ for length, width and height respectively. Fruit hopper side-slope $=$ more than maximum friction angle of Ponkan mandarin fruits with stainless steal surface $\left(>17^{\circ}\right)=30^{\circ}$.

Grading drums: Revolving drums with holes are used to grade the fruits to 5 sizes. Drum hole diameters $=40,50,60,70$ and $80 \mathrm{~mm}$. No. of drums to suit No. of Ponkan mandarin categories $=5$. Rotating drums with holes diameter and length to suit machine productivity $=$ about $40-$ $50 \mathrm{~cm}$ diameter and $100 \mathrm{~cm}$ length. Drums tilt-angle $=$ more than 
maximum rolling angle between Ponkan mandarin fruits and stainless steal surface $=$ more than $24^{0}$.

Fruit chute tilt angle $=$ more than maximum friction angle between Ponkan mandarin fruits and stainless steal surface $=$ more than $17^{0}$.

\section{REFERENCES}

Agamia, E. H.; Nageib, M. M. and Tamahy, M. M., 1982, Evaluation of six varieties of mandarin, Nat. Res. Cen, Dokki, Cairo, Egypt, Annals of Ag. Sc., Moshtohor, 18: 225 - 233.

Atta-Aly, M. A. and Awady, M. N., 1994, Safety and accuracy of a nondestructive deformation tester manufactured in Egypt for measure tomato fruit firmness, Annals Agric. Sci., Ain Shams Univ., 39(1): 307-318.

Awady, M. N.; Yehia, I. Hassan, M. A. and El Lithy, A. M., 2004, Some physical and mechanical properties of Minneola fruits, Misr J. Ag. Eng., 21(2): 669-684.

Buyanov, A. I. And Voronyuk, B. A., 1985, Physical and mechanical properties of plants, Fertilizers and Soils, Amerind Pub. Co., PVT, LTD, New Delhi, Bombay, Calcutta, New York: 15 - 97.

H. R. I. (Hort. Res. Inst.), 2004, Data on citrus statistics, Oral communication with Prof. Dr. Latif, Sen, Res., Citrus Div., Hort. Res. Inst. (H. R. I.), ARC.

Kinawy, A. H., 1995, A comparative study on two mandarin cultivars, M. Sc., Hort. Dept., Fac. of Ag., Al-Azhar U.: 1 - 168.

Khanali, M., Varnamkhasti, M. G., Tabatabaeefar, A. and Mobli, H., 2007, Mass and volume modeling of tangerine (Citrus reticulate) fruit with some physical attributes, Int. Agrophysics, Iran, 21: 329-334.

Mohsenin, N. N., 1986, Physical properties of plant and animal materials, Gordon and Breach Sc. Pub., N. Y.

Mousa, M. M., 1998, Engineering factors affecting the development of grading machine for citrus, Ph. D., Fac. of Ag., Cairo U.: 126-255.

Peleg K., 1985. Produce Handling, Packaging and Distribution, linear form: AVI Publ. Comp. Inc., Westport, Co., USA.

Sharawy, A. M., 1992, A compartive study of some citrus species and varities grown in Egypt and Sudan and the effect of environmental 
factors on the quality of fruits and yeild, M. Sc., Sc. In African Stud. Inst., Cairo U.: 25 - 94.

Saunt, J., 1990, Citrus varities of the world, Sinclair Int. Ltd., Norwich, England: 49 - 61.

Yehia, I., 2001, Design and construction of an automatic orange-juice extraction system, 9th Conf. of Misr Soc. of Ag. 9-11 Sept.: 147162.

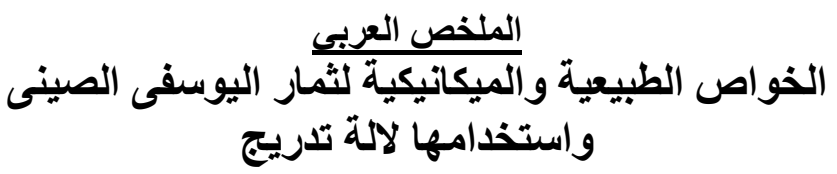

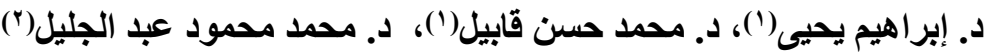

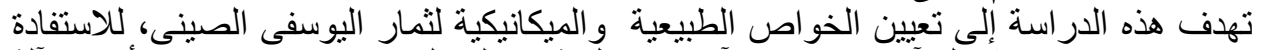

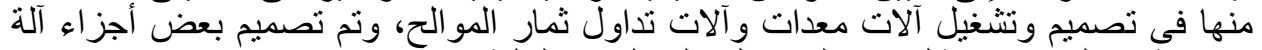
تدريج ثمار اليوسفى كمثال. وتم الحصول على الثى النتائج التالية:

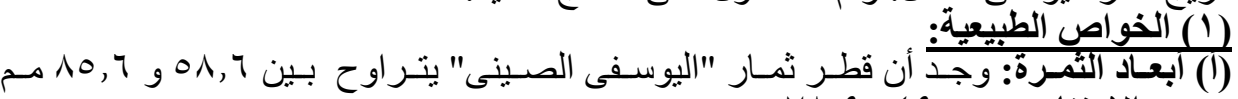

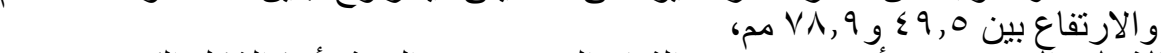

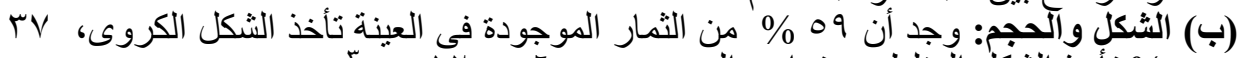

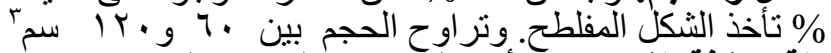

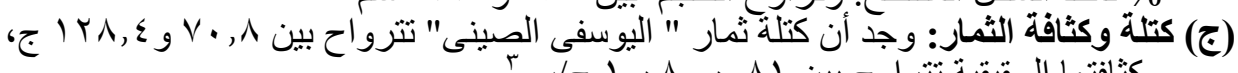

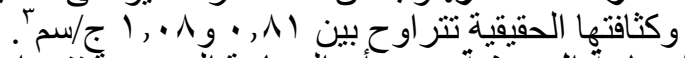



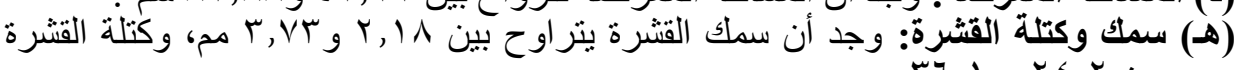



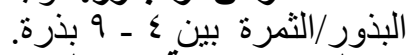

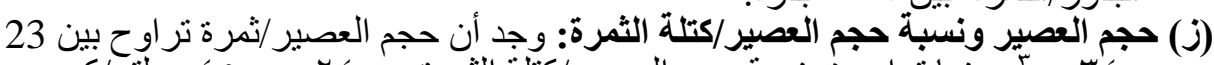

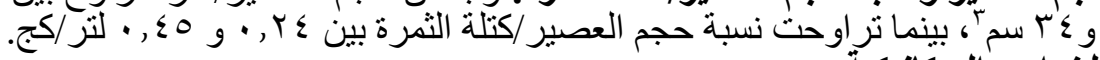
(r) (r) الخواص الميكانيكية:

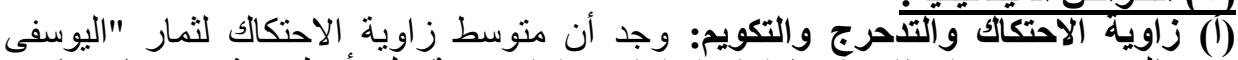

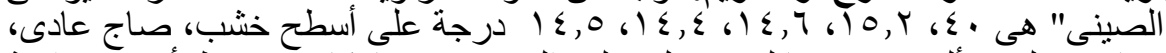



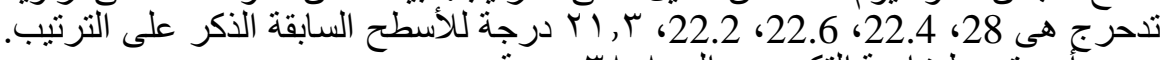



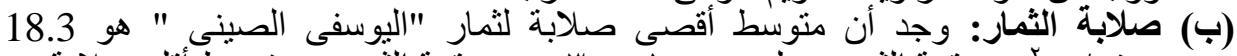

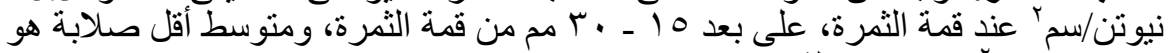
11 نيوتن/سمَ عند قاعدة الثمرة.

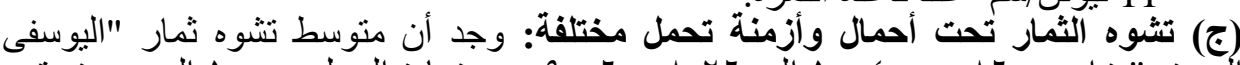

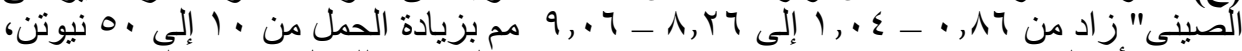

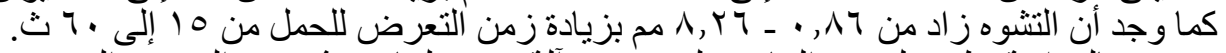
وبالدر اسة تطبيق لبعض النتائج على تصميم آلة تدريج ليناسب ثمرة "'"اليوسفى الصينى ( (1)، (r) باحث أول و باحث على الترتيب، معهد بحوث الهندسة الزر اعية. 